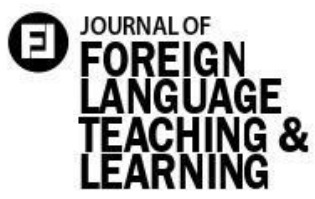

Volume 4, No. 1, 2019

Available online at: journal.umy.ac.id/index.php/FTL/issue/view/579

\author{
David Sulistiawan Aditya \\ is an English lecturer at \\ Universitas 'Aisyiyah \\ Yogyakarta. His current project \\ is investigating the use of \\ mobile technologies in tertiary \\ education. His research interests \\ are in the area of Educational \\ Technologies and Mobile \\ Assisted Learning.
}

\section{"BEM" An Android Application Model to Enhance Midwifery Students English Speaking Competence}

David Sulistiawan Aditya

Universitas 'Aisyiyah Yogyakarta

davidsaditya@unisayogya.ac.id

DOI: $10.18196 / \mathrm{ftl} .4137$

\begin{abstract}
The lack of exposure and practice in learning English due to the short meeting hours is the main factor contributing to the low level of midwifery students' English-speaking competence in Indonesia. Mobile-Assisted Language Learning can be one of the ways to cope with this problem. A plethora of learning speaking applications is available in the App Store and Play Store. However, midwifery students need more specific English to meet their needs. This study aims at developing a model of android application to enhance the speaking competence of midwifery students and anchors in the instructional design model. The design was in the five stages, namely: Analyze, Design, Develop, Implement, and Evaluate. Twenty-one midwifery students and two experts of material development and information technology were participants for product implementation and evaluation. The researchers obtained the necessary data through observations, questionnaires, and interviews. The finding of this study was that an android application model named BEM (Basic English for Midwives) developed in this study could enhance the midwifery students speaking competence.
\end{abstract}

Keywords: Android Application; Speaking Competence; Mobile Assisted Language Learning 


\section{Introduction}

$$
\text { English competence is still a }
$$

problem for Indonesian healthcare professionals. The Indonesian Minister of Health, in Republika.co.id, states that the demand for nurses and midwives from outside countries is immense. The Indonesian government has signed an $\mathrm{MoU}$ with some countries such as Saudi Arabia, Japan, Netherlands, and Qatar. They need around 20.000 health professionals from Indonesia, Philippine, and Vietnam. However, she mentions that Indonesian health professionals still have problems with language, especially English. Most countries require migrant health professionals to meet their language competence standard as regulated by every countries' government, and it is a barrier for most international health workers including from Indonesia, to work outside countries. Thus, "language competence has become a priority as health care workers need to be able to communicate safely with patients and coworkers, help patients make informed decisions, and keep clear patient records" (Rumsey, Thiessen, Buchan, and Daly, 2015, p.5).

The low English proficiency of Indonesian healthcare professionals was the effect of the lack of exposure from English learning in colleges (Maharani, 2013). Even though English has been a compulsory subject at most Indonesian health schools, it is not as the language of instruction taken at the beginning of the course within one or two semesters with small credits. In most Indonesian Health Colleges, English subject normally has 14 meetings in one semester. The number of interactions in meaning that students participate in language learning will influence language acquisition success (Kusmaryani, 2019). As a consequence, when students have less time to use the language to interact and participate, the acquisition of the language is also limited.

Current innovation in mobile technology presents learning innovation for EFL learners, which is learning beyond the classrooms (Kukulska-Hulme, Norris, and Donohue, 2017). Language educators have started integrated mobile technology as a solution to current problems in EFL teaching and learning. Several previous studies showed the effectiveness of the integration of mobile technology in English instruction. In Indonesia, Wulandari (2019) made use of Instagram Vlog to enhance speaking skills, enrich vocabulary, and build students' confidence and motivation in learning. In another study, mobile applications had proven optimizing 
students' speaking skills and critical thinking in English learning (Kusmaryani et al., 2019). Accessing English Monolingual Dictionary (EMD) through mobile phones could boost students' listening skills (Yudhiantara \& Saehu, 2017). Other mobile-assisted learning namely BusinessApp (Calle, Pomposo, \& ParejaLora 2015), VISP or Videos for Speaking (Moreno \& Vermeulen, 2015), ANT or Audio News Trainer for English (Barcena \& Read 2015) were other mobile assisted language learning which successfully gave contribution to the success of English learning for various purposes.

Android is one of the operating systems widely used in Indonesia. Android is considered a suitable platform to be integrated into classroom instruction and well developed in the MALL. A plethora of applications in the Android play store is accessible for learning English speaking. However, midwifery students need more specific English to meet their learning objectives. App Inventor is an online android application developer provided by Google which enables teachers with little knowledge of programming to create an android application as it does not use a lexical language program.

This study focuses on developing a mobile-assisted language learning media, particularly designing a model of android application as a media to enhance the English speaking competence of midwifery students' in the first-semester at Universitas 'Aisyiyah Yogyakarta. This study answers these two research questions:

- What is an android application model to enhance English speaking competence of midwifery students at Universitas 'Aisyiyah Yogyakarta?

- What are the impacts of the model on the speaking competence of midwifery students?

\section{Literature Review}

\section{Mobile Technology for Learning}

Mobile technology has been discussed recently to support learning in various contexts. Mobile learning is associated with learning opportunities served through interactive mobile devices, and the learner accesses resources provided at a fixed location or while on the move (Abidin, Mathrani, Hunter, \& Parsons, 2017). Mobile devices allow the learner to choose the time, location, and a comfortable pace for learning while helping teachers to provide personalized and motivating learning experiences to suit the learning location and context (Sivakumar, 2014). In recent decades, mobile technologies have dramatically improved concerning its use for 
learning in various subjects. Sung, Chang, \& Liu (2016) reviewed a hundred publications related to the use of handheld devices for learning. They revealed that the publication related to the integration of mobile technologies in learning situation from 2004 to 2008 was less than 20 publications and increased significantly to more than 60 publications within 2009 to 2013 and most of the innovation was taken to formal education and on Languages and Arts subject then followed by Science and Mathematics. It seems to keep growing until now in various educational contexts and subjects.

Many previous types of research related to technology-enhanced learning, particularly in the area of mobile-assisted learning, have made a positive contribution to the development of teaching and learning (Kusmaryani, Mustafa, \& Purnawarman, 2019). Wulandari (2019) made Instagram enhance students' English-speaking competence. Awan et al. (2019) integrated learning with a mobile game in Radiology Education, and Yudhiantara \& Saehu (2017) optimized the access of the English Monolingual Dictionary (EMD) through mobile devices to help learners to enhance their listening skills in English teaching.

However, the growth of mobileassisted learning has faced challenges in some countries, including Indonesia. France, started September 2018, has banned mobile phones at schools due to its negative impact on students claiming that the students use it for adult access, cyber-crime, and violence content. However, it seems that they have not conducted a deep study of factors contributing to its negative impact and do not consider its potential for students learning. The same situation happens in Indonesia, although there is no official government regulation yet related to the ban of mobile technologies at schools coming from teachers and school managers. In the meantime, mobile learning has become fashionable nowadays.

\section{Mobile-Assisted Language Learning}

The innovation of mobile technology for the development of teaching and learning English has been studied since the last decades and mostly in the area of languages and arts. Utilizing mobile technologies in language learning is well known with term MALL or Mobile-Assisted Language Learning. The studies of MALL tended to focus on formal learning contexts and seek enhancements in language skills and competencies such as reading, writing, speaking, listening, and vocabulary acquisition (Kukulska-Hulme, 2016). Although most of the kinds of literature in 
MALL have not proven to give better results on student's language skills compared to face to face class, it provides a lot of opportunities for students to have more exposure in learning and well-suited media for current learning problems and situation.

Some principles need to consider in designing MALL media. Elias (2011) has analyzed eight general principles in designing MALL and interprets those principles for mobile learning. Four of them are considered to give value to the MALL:

o equitable use, "deliver content in the simplest possible format;"

o flexible use, "package content in small chunks;"

o tolerance for error "scaffold and support situated learning methods;"

o instructional climate, "push regular reminders, quizzes, and questions to students."

Besides, Stockwell (2013) formulates the other principles. He proposes ten principles of designing instruction in MALL. They are 1) mobile activities, tasks, and apps in MALL should consider the affordances and limitations of the mobile device and the environment where the device implemented, 2) reduce the need of multi-tasking and distractions to the environment, 3) can motivate as well as show boundaries, 4) provide equity, 5) be aware of and accommodate the differences of the language learner, 6) consider used devices and the cultures, 7) provide short and succinct tasks and activities, 8) fit the tasks with the technology and the environment with the task, 9) provide assistance and training to use the mobile devices for effective learning, 10) recognize and accommodate varied stakeholders.

\section{Methodology}

This study developed and examined a model of Android application as learning speaking media for the midwifery students and investigating the impact of it on the students' speaking competence. It employed an instructional design approach as guidance to work on product development and qualitatively investigated for its impact. Instructional design is the development of instructional theory through the systematic procedure to ascertain the instruction quality (Berger and Kam, 1996). The instructional design consists of ADDIE that shows the phases of the design, namely 1 . Analyze, 2. Design, 3. Develop, 4. Implement, and 5. Evaluate. The design is as follows. 
Figure 1. Instructional Design Model

(Rogers, 2002)

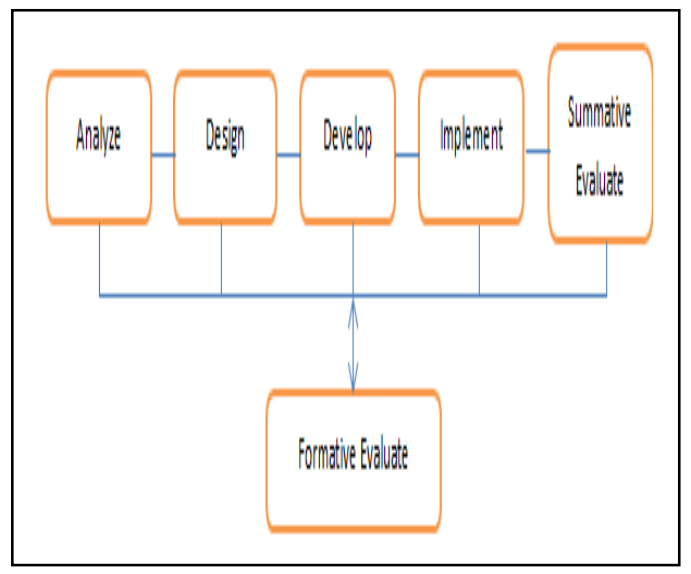

The product development started with the analysis of learners' target and learning needs. The analysis process reviewed the first-semester English curriculum document for the midwifery program in the university and also the context and language situation that they needed to use in the midwifery context through a focused group discussion with the midwifery lecturers and the English teacher to specify the language focuses and terms for the learners. After the learning materials had identifications, the storyboard was then designed based on the activities of the material to accommodate the speaking tasks in the platform. The researcher used App Inventor to developing the storyboard into an application. When the platform was ready, the experts evaluated it. Revision and improvement were made based on the experts' evaluation before implementing the product. The researcher implemented the final version to the research subjects for one semester teaching period of an English class from November 2016 - February 2017, and 21 midwifery students in the first semester were the participants for the product implementation. The samples taken were through total sampling. Pre-test and post-test of English-speaking were conducted to uncover the impacts of the platform on learners' speaking competence. Finally, interviews and questionnaires were posed to understand further the impacts. Figure 3 gives a clear description of the study process.

Figure 2. The Description of Study

\section{Process}

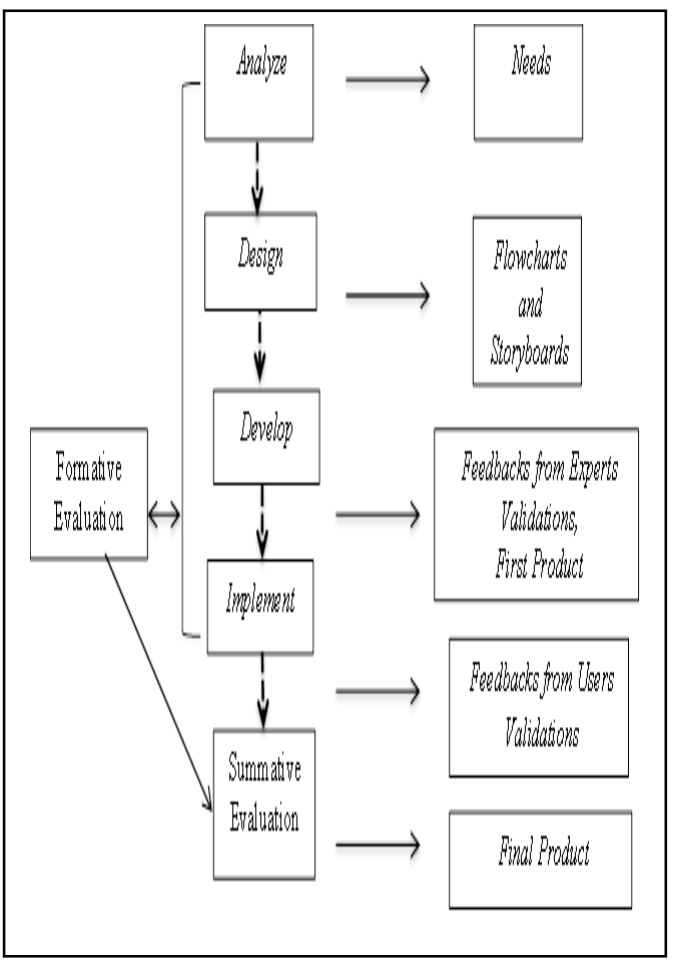


Findings

\section{Description of the Product "BEM"}

The output of the study was a mobile application model as a learning media of English speaking for midwifery students at the beginner level. The application was named Basic English for Midwives or "BEM" with android as its operating system. The size of the app was 10.9 MB. BEM contained five topics and five English speaking activities within every topic as the core of speaking activities conveyed in the application. In the first activity, the learners listened to an audio of conversation based on the context of the topic, learned language functions and expressions being used by the speakers in the context. The second activity provided the learners with pronunciation practice of single words. The learners could listen to the correct way of pronouncing some words related to the topic and check their pronunciation quality through the platform. In the third activity, the learners were still having practices on pronouncing words but more into sentences and expressions in English.

Meanwhile, activity four gave the learners more exposure to discourse situations by completing a dialogue. Finally, the last activity would allow the learners to explore speaking practices through a video project of monologue or dialogue context in English. The content of BEM is as follows:

Figure 3. The Parts of BEM

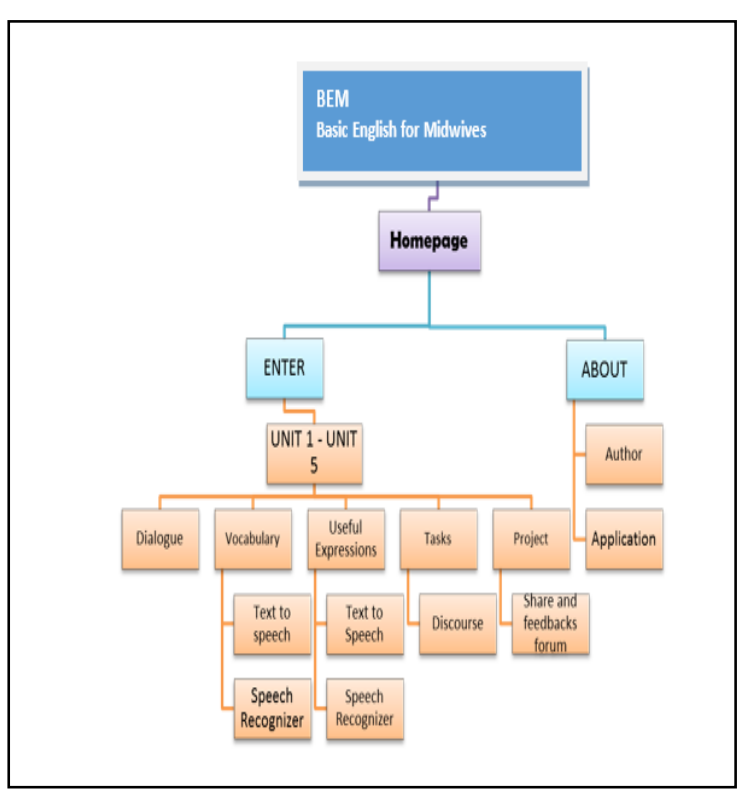

The chart illustrates the sections and features of the model of BEM. As the product features were planned carefully in the initial process, only a few changes were made on the prototype to get the final product. There was a change made in activity 4 of the product, which was before jumbled words activity. After getting feedback in the expert evaluation, the researcher modified activity in the form of discourse analysis activities through multiple choices. 
Figure 4. The User Interface of

\section{BEM}

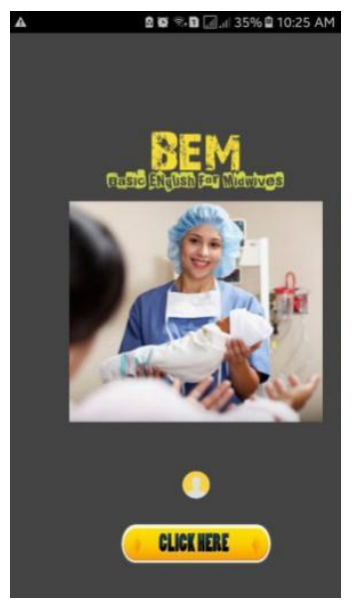

The activities of BEM adapted the frame of the cycles of teaching speaking proposed by Goh \& Burns (2012) and principles in teaching speaking in EFL formulated by Nunan (2003). While to construct the product as a mobile-assisted learning media, the researcher grounded the construction on the principles of mobileassisted language learning (Stockwell, 2013), and well-designed software (Elias, 2011).

\section{Discussions}

The product's accountability development was through the experts' evaluation in terms of media and material. The researcher gathered evaluation through questionnaires in the forms of the Likert scale, and the open-ended questions were also employed to get vivid and valuable feedback. The result of the mean score of the learning material in the product was 1.9. The score denoted that the learning resources in BEM were appropriate to facilitate the teaching and learning of English-speaking skills, particularly to midwifery students. From the open-ended questionnaire data analysis, the expert concurred that the learning recourses in BEM were worthwhile to provide students with activities to enhance their Englishspeaking skills.

Furthermore, the expert also acknowledged that the learning activities in BEM were easy to understand, interesting, and fun for learning. It indicated that the first phase in the cycles of teaching speaking applied in the product as it focuses on guiding the learners' attention in speaking practices. Also, the activities provided that are interesting and fun will internalize students' motivation and promote attention to practice their speaking. The expert added up that the learning resources in BEM provide activities that guide the language learners in learning English sentence stress and speech sounds. The resources were also considered to enrich the students' range of vocabulary. For instance, the activity one and two provide learners with vocabulary and pronunciation drills. Yet, the product 
set the learners in learning of language functions and expressions. Finally, the materials in BEM served in specific terms and contexts of the purpose of learning English. All in all, the materials in BEM were appropriate to sanction the learning of English-speaking skills to midwifery students.

Meanwhile, in terms of quality as a learning media, the result of data showed that the mean score was 0.6. It indicated that the expert's opinion on BEM as a mobileassisted learning media was positively high. The application worked as good media for learning. The expert admitted that the BEM was practical and interesting for learning the language. In terms of its user interface, he acknowledged that the application was easy to operate, and it accommodates the varied technical knowledge of both teachers and students. However, some parts of the product required improvements. First, background color and text color required adjustment since some of them similar. Contrast color was the suggestion for improvement. Second, buttons on the interface seemed not consistent in its location on some screens. Orderliness was the requirement for the quality of the user interface. Third, initial authentication, such as the "login" component, was required to be able to build a system to record learner's progress in doing the activities. Fourth, the back button needed to be created to make navigation easier for the learners. Finally, the experts found that some features in the app did not work when installed on certain devices. The version of the operating system in the devices, the android developer application (App inventor) version, and screen size or resolution affect the product's compatibility.

After the product was improved based on the experts' evaluation, the researcher implemented it in the field. One of the English classes of the Midwifery department became the research subject randomly. The class consisted of 21 midwifery students considered as beginner learners. The researcher guided the teacher in product integration in the teachinglearning process. It found out that two students were unable to use the product because their mobile phones belonging to the IOS operating system. The product had consistent integration into both the classroom instruction and as supplementary outside the classroom through self-learning project instructed by the teachers.

At the end of the class, the speaking competence of the participants indicated improvement through the implementation of the product. The improvement was a denotation through a speaking test in the 
pre and post of the teaching and learning process within a semester. Table 1 delineates the results of the score of the pre-test and post-test of speaking skills within the study, which covers four components, namely vocabulary range, pronunciation, grammar, and fluency. The researcher conducted himself and not the class teacher to avoid subjectivity in the scoring processes. It was face to face speaking test.

Figure 3. The Result of Pre and Post Speaking Test

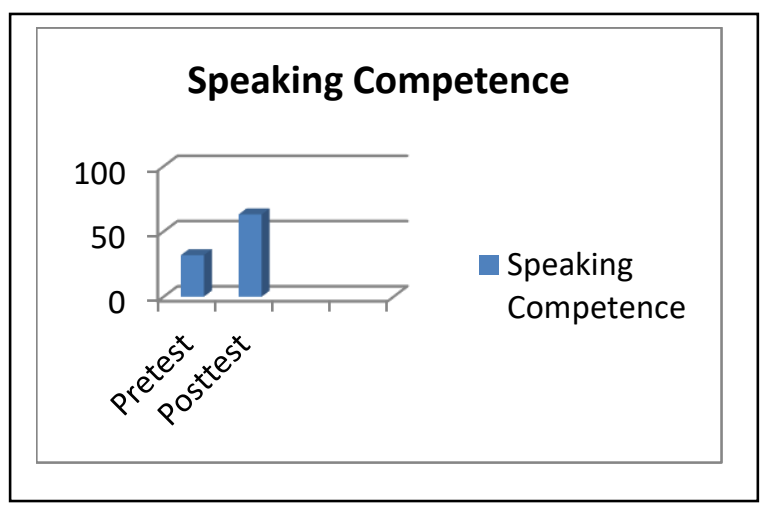

The score of the pre-test denotes that the participants had a low speaking competence. The students' average score of their speaking test was 31.9. After the product was employed and integrated into the process of English teaching and learning by the teacher within a semester under the researcher's assistance, the participants
English speaking average scores increased to 63.1. It indicated that the product influenced the students speaking competence.

The researcher also gathered participants' perceptions to obtained feedback and the leverage of the product to participants. The data taken through openended questions and semi-structured interviews signified that learners had a positive perception of BEM. They pointed out that BEM was a practical tool to help them to improve their speaking skills. The app was also practical to be installed by the learners independently. They stated that BEM was a proficient media to facilitate them in learning English speaking both in the classroom instruction and outside the classroom as supplementary learning resources as BEM provided them with fun activities, opportunities to have more English-speaking practices, and also constructive feedback. The participants also acknowledged that BEM helped assist them in learning to pronounce words and enriching vocabulary. They admitted that they had difficulties in pronouncing English words. Thus BEM was worthwhile to help them out with that problem.

Similarly, the product was also giving them a comfortable situation in practicing their English speaking. As English is not the 
second language that Indonesian people use in their daily and academic situations, it culturally impacted the students' selfconfidence in practicing it in public/open situation. The students argued that they felt more comfortable to have their Englishspeaking practices through the phone rather than in the class. They added that doing speaking practice through the BEM individually gave them no anxiety, especially when they made mistakes. They could do it over and over again without worrying about their friends making fun of it. Finally, they described that doing vlog as the last project of the platform activities was such a hobby for them. Making a video project as the final project of the platform in every theme could arouse their motivation to learn to speak.

However, they also reiterated that teacher's control and guidance were necessary to learn English speaking through BEM. The appropriate policy should be designed to avoid the negative impact of mobile technology (Machmud, 2018). Some of them admitted that they were distracted to access social media when they were learning using their mobile phones. A few were doing the activities in a short time and close to the deadline merely to fulfill the class requirement. They also mentioned technical problems when they access it outside the class. The students' mobile phone data space limitation and data internet connection were problems the teacher should consider to integrate this app in their English speaking class.

\section{Conclusion and Implication}

BEM is an android application which is accountable to be a tool to provide opportunities for speaking practices and as supplementary material to learn English speaking skills for current midwifery students both in the classroom and mobile situations to solve the short meeting hours problem. It consisted of five themes in which the researcher designed five speaking activities by considering the teaching speaking cycles and principles of designing MALL. The product received evaluation and modification based on experts' validations in terms of both media and material. In its implementation, the students speaking competence showed improvement, and the researcher measured it using pre and posttest within a one-semester learning process from the initial average score of 31.9 to 63.1. Also, most of the students had positive perceptions of using BEM to learn English speaking. BEM was a practical tool to help them to improve their speaking skills. Yet, it provided them an ease situation to learn and practices English speaking. 
Future researchers need to consider

some technical problems if they are going to implement a similar topic. Teacher control is needed to make sure that the students do the learning as phone access will direct them to access social media. Other variables might also influence the results of this study, namely motivation, learning intensity, teaching method, students' socio-economic background, culture, and other variables. Possible influencing variables need consideration for future study. Thus, an experimental study needs to explore the product's effectiveness in enhancing language learners' speaking competence.

\section{References}

Abidin, Z., Mathrani, A., Hunter, R., \& Parsons, D. (2017). Challenges of Integrating Mobile Technology into Mathematics Instruction in Secondary Schools: An Indonesian Context. Interdisciplinary Journal of Practice, Theory, and Applied Research, O(0), 1-16. doi. 10.1080/07380569.2017.1344056

Awan, O. et al. (2019). Making learning fun: gaming in radiology education. Academic Radiology, 26 (8), 1127-1136. doi.org/10.1016/j.acra.2019.02.020

Bárcena, E. et al. (2015). State of the art of language learning design using mobile technology: sample apps and some critical reflection. Critical CALL Proceedings of the 2015 EUROCALL Conference, Padova, Italy, 36-43. doi.org/10.14705/rpnet.2015.000307

Berger, C. \& Kam, R. (1996). Definitions of instructional design. Retrieved from http://www.umich.edu ed626/defin/html on September 14, 2015.

Calle, C., Pomposo, L., \& Pareja-Lora, A. (2015). BusinessApp: Una aplicación para el aprendizaje del inglés mediante dispositivos móviles en el campo de los negocios. E-Aesla, 1. Retrieved from http://cvc.cervantes.es/lengua/eaesla/p df/01/19.pdf

Elias, T. (2011). Universal instructional design principles for mobile learning. International Review of Research in Open and Distance Learning, 12(2), 143-156. Retrieved from http://www.eric.ed.gov/PDFS/EJ9207 38.pdf

Goh, C. C. M. \& Burns, A. (2012). Teaching Speaking: A Holistic Approach. Cambridge: Cambridge University Press.

Handayani, L. S. (2018). Menkes dorong perawat kerja di luar negeri. Retrieved from

https://www.republika.co.id/berita/nas ional/umum/18/12/20/pk1g0a430menkes-dorong-perawat-kerja-di-luarnegeri

Kukulska-Hulme, A. (2016). Mobile Assistance in Language Learning: A critical appraisal. In: Palalas, Agnieszka and Ally, Mohamed eds. The International Handbook of Mobile-Assisted Language Learning. Beijing: China Central Radio \& TV University Press Co., Ltd.

Kukulska-Hulme, A., Norris, L., \& Donohue, J. (2015). Mobile pedagogy for English language teaching: a guide for teachers. ELT Research Paper. London: British Council.

Kusmaryani, W., Musthafa, B., \& Purnawarman, P. (2019). The influence of mobile applications on students' speaking skill and critical thinking in English language learning. International Conference of Computer and Informatics Engineering (IC2IE). Journal of Physics. Conf. Ser. 1193 012008,1-6. 
doi: $10.1088 / 1742$

6596/1193/1/012008.

Kusumawardhani, A. (2017). Kebutuhan perawat: kawasan asia timur meningkat. Retrieved from http://industri.bisnis.com/read/20170 726/12/675208/kebutuhan-perawatpermintaan-kawasan-asia-timurmeningkat

Machmud, K. (2018). The smartphone use in Indonesian schools: the high school students' perspectives. Journal of Arts $\mathcal{E}$ Humanities, 7(03), 33-40. dx.doi.org/10.18533/journal.v7i3.1354

Maharani, D. F. (2013). Moodle Learning Model for Nursing Students of POLTEKKES. A Thesis. Yogyakarta: Sanata Dharma University.

Moreno, A. I. \& Vermeulen, A. (2015). Using VISP (Videos for Speaking), a mobile app based on audio description, to promote English language learning among Spanish students: a case study. Procedia-Social and Behavioral Sciences, 178 (2015), 132-138. doi.10.1016/j.sbspro.2015.03.169

Nunan, D. (Ed.). (2003). Practical English language teaching. New York: The McGraw-Hill Companies.

Rogers, P. L. 2002. Designing Instruction for Technology-Enhanced Learning. Hershey. PA: Idea Group Publishing.

Rosalina, E. (2016). Indonesia Alami Kelebihan Tenaga Kesehatan. Retrieved from http://www.bnp2tki.go.id/read/11779 /Deputi-KLN-dan-Promosi-BNP2TKI-:Indonesia-Alami-Kelebihan-TenagaKesehatan

Rumsey, M., Thiessen, J., Buchan, J., \& Daly, J. (2016). The consequences of English language testing for international health professionals and students: An Australian case study.
International Journal of Nursing Studies 54 (2016), 95-103. doi.or/10.1016/j.ijnurstu.2015.06.001. Sivakumar. (2014). 3G - Mobile Technology In Education. Cognitive Discourses International Multidisciplinary Journal, 2(1), 49-53, retrieved from http://cdimj.naspublishers.com

Stockwell, G. \& Hubbard, P. (2013). Some emerging principles for mobile-assisted language learning. Monterey, CA: The International Research Foundation for English Language Education. Page 1-15. Retrieved from http://www.tirfonline.org/english-inthe-workforce/mobile-assistedlanguage-learning. On November $20^{\text {th }}$, 2014

Sung, Y, Chang, K \& Liu, T. (2016). The effects of integrating mobile devices with teaching and learning on students' learning performance: A meta-analysis and research synthesis. Journal of Computer and Education, 94 (2016), 252 275. doi.org/10.1016/j.compedu.2015.11.0 08

Tylor, J. (2011). AppInventor For Android. West Sussex: John Wiley \& Sons, Ltd. Wulandari, M. (2019). Improving EFL Learners' Speaking Proficiency Through Instagram Vlog. LLT Journal: A Journal on Language and Language Teaching, 22 (1), 111-125. doi.org/10.24071/1lt.2019.220111

Yudhiantara, R. \& Saehu, A. (2017). Mobile-Assisted Language Learning (MALL) in Indonesian Islamic Higher Education. IJELTAL (Indonesian Journal of English Language Teaching and Applied Linguistics), 2(1), 21-31. Retrieved from http://ijeltal.org/index.php/ijeltal/arti cle/download/52/pdf 